Chirurgia (2019) 114: 268-277

No. 2, March - April

Copyright $\odot$ Celsius

http://dx.doi.org/10.21614/chirurgia.114.2.268

\title{
Laparoscopic Mobilization of the Splenic Flexure as the First Step of Restorative Colorectal Resection
}

\section{Cătălin Copăescu, Loredana Bărbulescu, Victor Tomulescu}

Ponderas Academic Hospital Bucharest

\section{Corresponding author:}

Catalin Copaescu, MD PhD

Associated Professor of Surgery

Ponderas Academic Hospital

Nicolae Caramfil Street, no. 85 A

district 1, Bucharest, Romania

E-mail: catalin.copaescu@ponderas-ah.ro
Received: 10.03 .2019

Accepted: 15.04 .2019

\section{Rezumat \\ Mobilizarea unghiului splenic al colonului ca prim timp al rezecțiilor colorectale laparoscopice restaurative}

Introducere: Mobilizarea unghiului splenic al colonului este o etapă chirurgicală esențială în cadrul rezecțiilor colo-rectale restaurative. Pe de altă parte, această procedură chirurgicală este complexă din punct de vedere tehnic şi necesită o lungă curbă de învățare. Cu scopul îmbunătătirii rezultatelor postoperatorii, în 2016 am decis să efectuăm în mod uzual mobilizarea unghiului splenic ca o primă etapă a tuturor rezecțiilor sigmoidiene şi rectale laparoscopice/robotice. Scopul acestei lucrări este acela de a descrie tehnica mobilizării laparoscopice a unghiului splenic şi de a discuta avantajele utilizării acestei metode ca prim pas în rezecția colo-rectală, analizând experiența ultimelor 12 luni (2018).

Metodă: Tehnica laparoscopică de mobilizare a unghiului splenic colonic este descrisă detaliat. Există patru căi de efectuare a acestei tehnici chiurgicale: două dintre ele dinspre median spre lateral, unul pornind de la vena splenică, celălalt de la promontoriu, un abord superior, cranio-caudal şi unul dinspre lateral. Combinarea strategică a diferitelor căi de abord în vederea disecției unghiului splenic poate reprezenta o soluție fezabilă şi sigură, reducând morbiditatea şi timpul chirurgical.

Rezultate: In cadrul Poderas Academic Hospital, în perioada ianuarie-decembrie 2018, mobilizarea unghiului splenic ca prim pas al rezectiei colo-rectale s-a practicat la 47 de pacienți. Dintre aceştia, 30 de pacienți au fost operați pentru tumori rectale, 10 pentru tumori sigmoidiene, 5 pentru patologie benigna-diverticulită iar la 2 pacienți s-a practicat repunere în tranzit după rezecție recto- 
sigmoidiană tip Hartmann. Abordul robotic a fost utilizat la 40\% (16 pacienți). Nu au existat incidente intraoperatorii asociate mobilizarii unghiului splenic, nu a existat nici un caz de fistulă anastomotică colo-rectală, nu au apărut recidive tumorale precoce, decese sau complicații majore. Urmărirea medie a acestor pacienți a fost de 7 luni (interval 4-12 luni).

Concluzii: Din perspectiva noastră, mobilizarea de rutină a unghiului splenic ca prim pas al rezecțiilor de colo-rectale restaurative prezintă multiple avantaje şi această strategie chirurgicală ar trebui utilizată în mod curent. Într-adevăr, există o curbă de învățare lungă în obținerea unei expertize necesare efectuarii acestei proceduri chirurgicale, obtinuța cu mai mare uşurință în centrele specializate.

Cuvinte cheie: mobilizarea unghiului splenic, rezecția colorectală, anastomoza colorectală, rezultatele postoperatorii oncologice şi funcționale, chirurgia minim invazivă

\section{Abstract}

Background: Mobilization of the colonic splenic flexure (SFM) is an essential surgical step of the restorative rectal resections. However, the surgical procedures are technically complex thereby overcoming the learning curve may not be an easy process. Looking for improved expertise and better outcomes, in 2016, we have decided to routinely perform SFM as a first step of all the laparoscopic or robotic sigmoid and rectal resections.

The aim of this paper is to describe the technique of laparoscopic splenic flexure mobilization and to discuss the advantages of using it as the first surgical step in colorectal rectal resection analyzing our last 12 months experience (2018).

Method: A detailed description of the laparoscopic surgical technique for SFM is performed. There are four routes for SFM: two from medial to lateral, one starting from the splenic vein the other one from the promontory, a superior to inferior approach and a lateral to medial approach. However, the combination of different maneuvers for an easier, safer approach decreases the morbidity and is saving surgical time.

Results: Between January and December 2018, 47 patients had SPM as a first step of the performed colorectal procedure in our institution. There were 30 patients with rectal cancer, 10 with sigmoidal tumors, five with sigmoidal resection for diverticulitis and Hartmann reversal was indicated in two. The robotic approach has been used in 40\% (16 patients). No intraoperative incidents were associated with the SFM. No colorectal fistula was encountered. No early cancer recurrence, deaths or major complication were encountered. The mean follow-up for these patients is 7 months (range, 4-12 months).

Conclusions: In our perspective, the routine mobilization of the splenic flexure as a first step of the colorectal restorative resections associate many advantages and these strategies should be largely used. There is a learning curve involved in such procedure and it can easily be overcome in high volume centers.

Key words: splenic flexure mobilization, restorative colorectal resection, colorectal anastomosis, oncological and functional outcomes, minimally-invasive surgery

\section{Introduction}

Mobilization of the colonic splenic flexure was considered an essential and mandatory surgical step of the open approach for restorative rectal resections. However, its performance was not always easy and significant morbidity was associated with it $(1,2)$. 
The introduction of laparoscopic colorectal surgery had a positive impact on perioperative morbidity, due to its reduced access but also on eliminating the iatrogenic splenectomies (3). No-matter the strategy of taking down of the splenic flexure, medial-to-lateral, lateral-tomedial or the supramesocolic one, the procedure was still technically demanding and time consuming (4). Thus, its need for colorectal resections was subjected to many debates. Some authors argued on evidence that laparoscopic procedures without routine splenic flexure mobilization do not increase postoperative morbidity or oncologic risk and result in shorter operative time $(5,6)$ while other, found that mandatory splenic flexure mobilization is without merit or is without significant foundation in evidence (7). These studies suggested that laparoscopic rectal and sigmoid cancer resection can be safely conducted with selective splenic flexure mobilization" $(5,7)$. Opponent positions, underlined that routine mobilization of the splenic flexure for all anterior resections for cancer should be the norm, to avoid anastomosing thickened sigmoid colon, to facilitate the use of a J-pouch and especially to achieve a safe anastomosis without tension $(7,8)$.

Several studies filtered already that complete and not partial SFM offers better outcomes for the patients (9) while the lateral-to-medial approach is associating a significantly higher rate of intraoperative complications than the medial or anterior one (10).

The further progress of technology used in minimally-invasive surgery (MIS) brought more light in understanding the anatomy and dealing with the dissection of the colonic splenic flexure. As consequence, the increased surgical expertise for SFM opened the door of MIS to more complex operations: resections of splenic flexure tumors.

While the routine laparoscopic or robotic SFM is expected to have benefits on oncological and functional outcomes of colorectal resections, the described surgical procedures are technically complex thereby overcoming the learning curve may not be an easy process. Moreover, if the need of SFM will be considered after the rectal resection, the technical conditions and the surgical team fatigue may negatively influence the technical performance and the operative time. Looking for improved expertise and better outcomes, in 2016, we have decided to routinely perform SFM as a first step of all the laparoscopic or robotic sigmoid and rectal resections.

The aim of this paper is to describe the technique of laparoscopic splenic flexure mobilization to discuss the advantages of using it as the first surgical step in colorectal rectal resection analyzing our last 12 months experience (2018).

\section{Method}

\section{The Laparoscopic Surgical Technique for SFM}

\section{Preoperative set-up}

The patient's medical and oncological status should be carefully preoperatively assessed. During colonoscopy, aside the lesion evaluation, an endoscopic tattooing with Indian ink is recommended in all patients. A thoracic and abdominal CT scan is always necessary for cancer staging while the precise preoperative localization of the tumor is mandatory for laparoscopic resection planning. Virtual colonoscopy is routinely used, to improve cancer localization, to study the proximal colon in cases of non-complete endoscopic exam and to evaluate the descending colon length. Mechanical oral bowel preparation, perioperative antimicrobial (Cefuroxime), antithrombotic prophylaxis and a urinary catheter placed at the beginning of the procedure, are completing the preoperative work-up for SFM during colorectal resections.

\section{Patient position and surgical set-up}

The patient lays on the operative table in a split-leg supine position with both patient's arms along the body (French position). We found this position more useful as it allows enough perineal access for trans-anal maneuvers (to use the circular stapler or intraoperative exploration) while it is associating far less external conflicts for the laparoscopic instruments as compared with the Lloyd-Davies 
standard position for rectal surgery (11). The patient will be carefully secured on the operating table -using silicon pads and specific atraumatic supports for shoulders and legs -, to permit safe Trendelenburg and reversTrendelenburg while avoiding any postural complication during surgery. The operator and the first assistant are placed on the patient right side, with the second assistant between patient's legs. The video monitors are placed at the patient's left side and right shoulder, in front of the operator and second assistant, respectively. General anesthesia with orotracheal intubation and complete patient monitoring is required. Five 5-12 $\mathrm{mm}$ trocars are placed as it is depicted in Fig. 1: a $10 \mathrm{~mm}$ optical canula inserted on the mid-line, nearby the umbilicus, used for the endoscope, a $5 \mathrm{~mm}$ trocar in the right lower quadrant for the operator's right hand, a $12 \mathrm{~mm}$ trocar on the suprapubic area used alternatively for the surgeon's right hand and second aid, and 2 five $\mathrm{mm}$ trocars on the right and left abdominal flank, for the left surgeon's hand and the second aid, respectively. The trocar scheme should be flexible in number and positioning, according to the patient's characteristics or history of abdominal surgery. We are currently using a $45^{\circ}$ lateral view long endoscope connected to a HD camera and $42 \mathrm{~cm}$ long instruments for laparoscopic surgery (Karl STORZ, Tuttlingen, Germany). The CO2 pneumoperitoneum is initiated through-out a Verres needle inserted in the left hypochondrium and the gas intra-abdominal pressure is set to 12 $\mathrm{mm} \mathrm{Hg}$.

\section{Surgical strategies for SFM}

There are four routes for SFM: two from medial to lateral, one starting from the splenic vein the other one from the promontory, a superior to inferior approach and a lateral to medial approach (Fig. 2). However, the combination of different maneuvers for an easier, safer approach decreases the morbidity and is saving surgical time.

The intervention begins with an extended laparoscopic inspection, the identification of the rectal tumor, the evaluation of the colo-

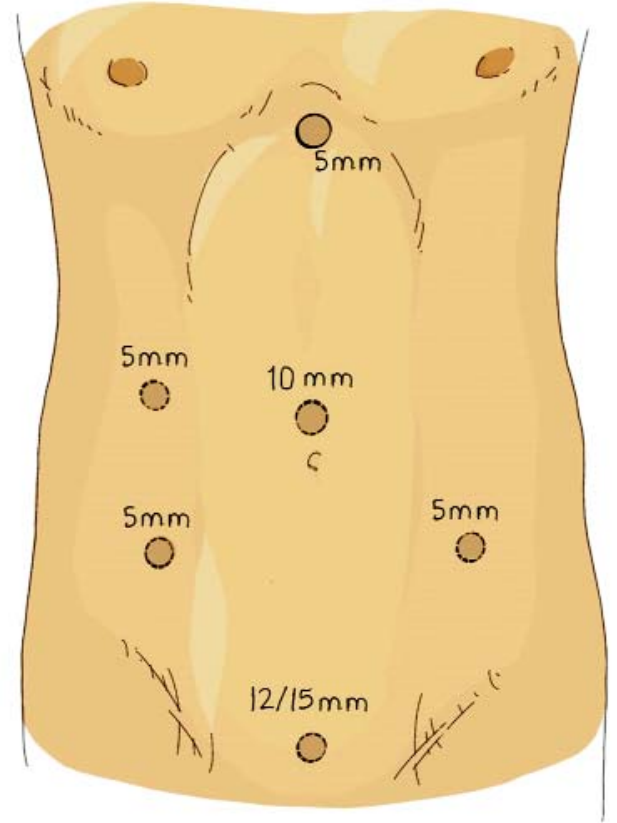

Figure 1. Trocar position for laparoscopic splenic flexure mobilization (SFM)

rectal anatomy and the completion the disease extension inventory, eventually by using laparoscopic ultrasonography liver examina-

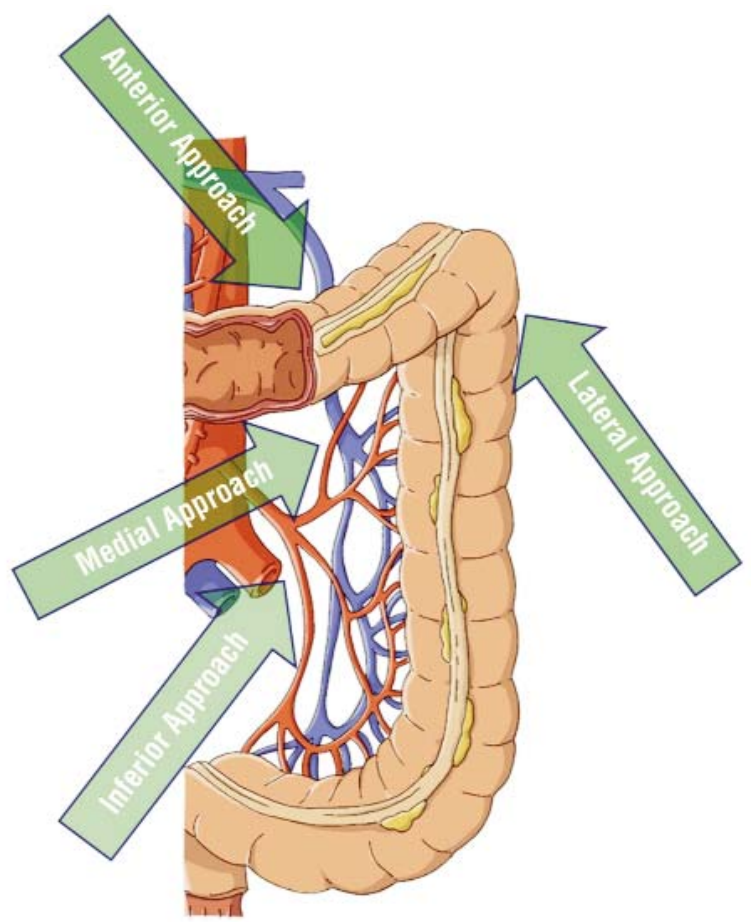

Figure 2. The surgical strategies for Laparoscopic Splenic Flexure Mobilization (SFM) 
tion. Sometimes, different positions of the operative table are required to fulfil all the tasks: steep Trendelenburg position, revers Trendelenburg, lateral tilt or horizontal position. Choosing between one the technical strategies for the SFM is sometimes depending to the anatomical findings and patient's characteristics.

For the medial-to-lateral approach, the ommentum is placed cephalad to the transverse colon and the small bowel is displaced to the right. The operating table should be in reverse Trendelenburg and tilt to the right. The inferior mesenteric vein (IMV), is identified lateral to the first jejunal loop and the duodenum, siding the aorta and inferior to the pancreas border, hidden behind the root of transvers mesocolon (Fig. 3) The assistant grabs the peritoneum near the IMV, and an incision is made on the peritoneum along the aortic border, parallel with the IMV. This opening performed by the scissors or monopolar hook will permit the pneumoperitoneum to invade the retroperitoneal space and helps us for the further dissection. At this stage, the IMV is circumferentially dissected, clipped with Medium-Large or Large Titanium Hemostatic clips and divided (Fig. 4). Care should be taken to preserve the ascending venous branch, destinated to the splenic flexure and to avoid

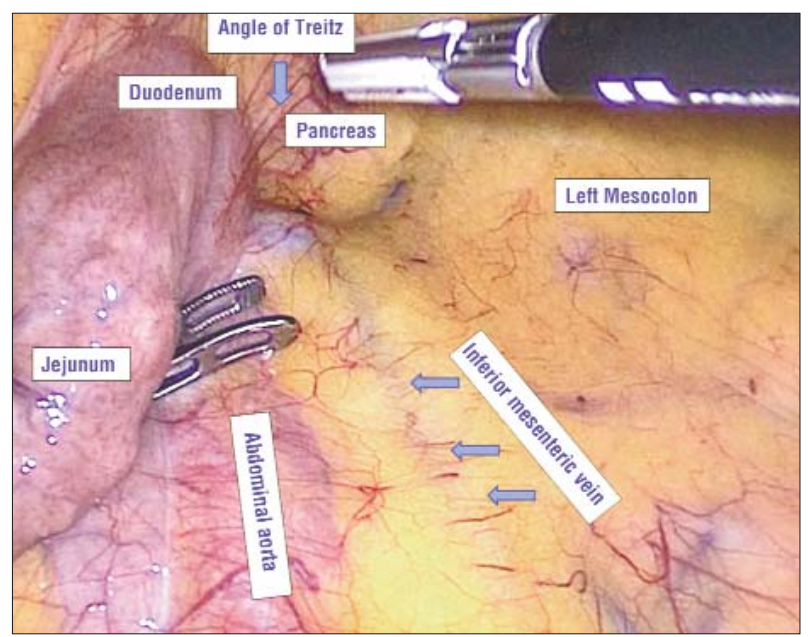

Figure 3. The medial-to-lateral approach. The inferior mesenteric vein (IMV), is identified lateral to the first jejunal loop and the duodenum, siding the aorta and inferior to the pancreas border

any injury to the left colic artery branches.

The optimal further dissection of the mesocolon follows embryologically-derived planes, succeeding in a reduced morbidity and ensuring a consistently reproducible technique. The plane should be developed along the Toldt fascia, having always posterior the fascia of Gerota. In this avascular plane, the dissection is safely and rapidly progressing, while the gonadal vessels and the ureter are less likely to be injured. In order to facilitate the dissection's progress, an atraumatic
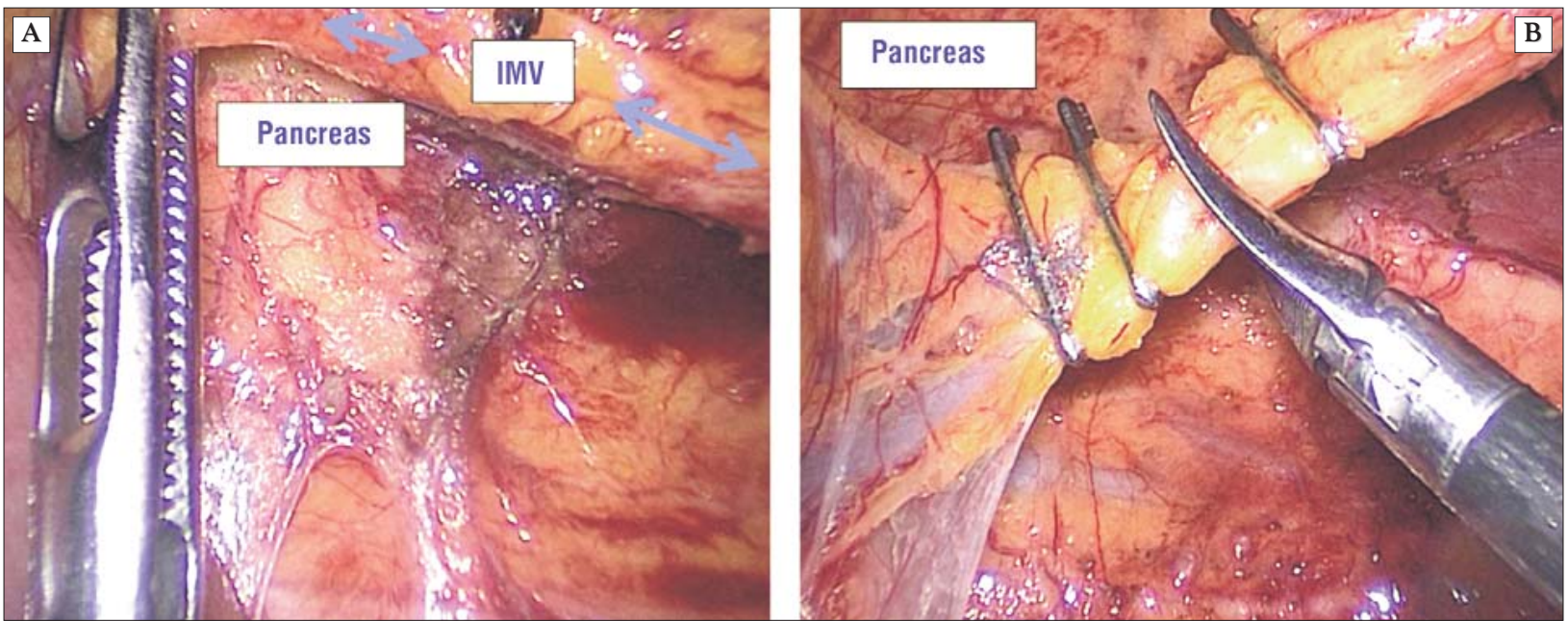

Figure 4. The medial-to-lateral approach for SFM. (A) A retromesocolic dissection is initiated medial to IMV. (B) Dividing the M at the inferior border of the pancreas 


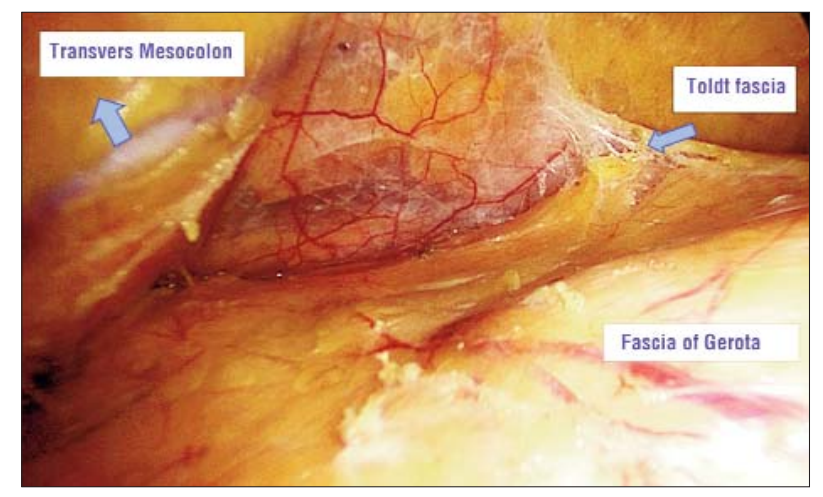

Figure 5. The medial-to-lateral approach - The plane is developed along the Toldt fascia, having always posterior the fascia of Gerota. An atraumatic gasper handled by the surgeon's left hand is lifting-up the mesocolon and colon

gasper handled by the surgeon's left hand is lifting-up the mesocolon while a sharp instrument (scissors or monopolar hook) is pooling down the thin white line of the Toldt fascia (Fig. 5). Care should be taken not to injure the vessel of the Riolan arcade.

Sometimes, a gauze grasped by a $5 \mathrm{~mm}$ fenestrated forceps positioned at this level can help for the atraumatic lifting of the mesocolon; a tent like space is generously being created, allowing the dissection toward the paracolic gutter; the gauze is latter left in the prerenal space to facilitate its recognition when the dissection is continued from above or from lateral.

As the inferior border of the pancreatic body and tail are identified, the transverse mesocolon is anteriorly divided, and enter the lesser sac is opened (Fig. 6). Scissors, monopolar hook or advanced bipolar energy devices are to be used for the mesocolon division. It is highly important not to injure the pancreas and pancreatic vein that is nearby. After we have entered the lesser sac, the dissection is continued to free the pancreatic tail and clearly see the spleen. At this stage, the peritoneal reflection of the left para-colic gutter can be easily divided by a lateral approach, as the pneumoperitoneum is clearly evidencing the line of dissection and the previously placed swab can be identified (Fig. 7)

The last thing to be done in order to com- $^{-}$

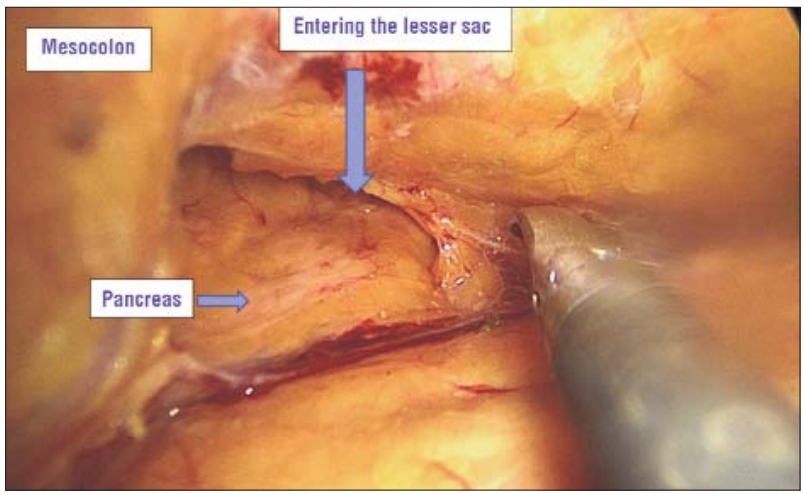

Figure 6. The medial-to-lateral approach for SFM. As the inferior border of the pancreatic body and tail are identified, the transverse mesocolon is anteriorly divided, and enter the lesser sac is opened

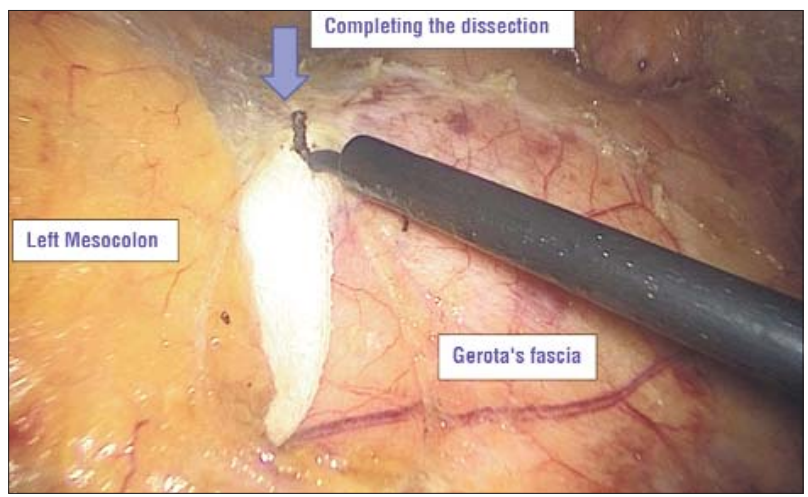

Figure 7. The medial-to-lateral approach for SFM -The peritoneal reflection isdivided by a lateral approach; The previously placed swab is identified

plete the SMF is the division of the gastro-colic ligament, lifted cranially together with the great ommentum, by using either the monopolar hook, the ultrasonic device (Harmonic Ace, Ethicon, US) or the advanced bipolar forceps (LigaSure, Medtronic, US).

When the SFM starts at the promontory, the patient is in steep Trendelenburg position and tilt to the right. The inspection of the pelvis and the rectal tumor inventory has finished and the SFM is initiated at this level. The incision of the peritoneum is performed on the right side of the inferior mesenteric artery (IMS) and vein (IMV). The hypogastric nerves are identified, the peritoneal incision is carried out cephalad, parallel with the IMV and the dissection continues cranially and lateral, progressively 
lifting-up the left mesocolon. The plan of dissection is the same avascular embryologic plane leaving behind the Gerota's fascia and is developed after a high or a low tie of the inferior mesenteric artery. A change of the position of the operation table to ReverseTrendelenburg is needed for the next surgical steps of the SFM. As this stage, the surgical strategy is similar as for the medial-to-lateral approach is was described above.

The superior-to-inferior approach or the supramesocolic approach starts with division of the gastro-colic ligament. Dissection starts at the distal transverse colon. The aim is to separate them, along the embryological plane that exists between the greater ommentum and the transverse colon. It is highly important to remember that, there are 2- 4 layers of dissection at this level and care should be taken not to injure the colon and paracolic vessels arcade during their surgical separation. We can use different instruments for this step: scissors, ultrasonic scalpel, or monopolar hook. Then, the lateral attachments of the descending colon are divided. The colon is inferiorly mobilized and the SF mesocolon is dissected from Gerota's fascia. It is important to rich the correct plan from the beginning of the dissection, looking for the white line of Told' fascia. Following this important landmark, an avascular embryological plan of dissection is further developed. The dissection should be carried out near the colon; a different plan opens the Gerota's fascia and enters a bleeding perirenal fatty tissue. Further, the dissection goes inferiorly to detach the left mesocolon in the same plan, "to open it as a book" and then medially till the inferior pancreatic border is exposed. If a larger mobilization is needed, the transverse mesocolon is more dissected from the pancreatic body and tail.

The lateral-to-medial approach starts at the level of the left paracolic peritoneum reflection (left paracolic gutter) with the incision of the peritoneum. We prefer to use de monopolar hook for this dissection. The ascending colon is medially rotated by means of an atraumatic grasper, and the posterior aspect of the left mesocolon is evidenced. The dissection is continued along the white line of Told's fascia, in front of the Gerota's fascia, progressing next to the colon. Care should be taken to avoid a wrong plan of dissection that can be developed behind the kidney or in the perirenal fat. The dissection advances medially until the inferior border of pancreas is reached. Then the ommentum is freed from the parietal adhesions and, with the help of the assistant, it is mobilized cephalad. The dissection of the ommentum and gastrocolic ligament is developed medially, staying nearby the colon; As there are multiple layers of dissection at this level, care should be taken not to injure the colon or the Riolan's arcade. After entering the lesser sac, we continue the dissection until the spleen is evident and splenic flexure is mobilized. At the end, the attachments of the mesocolon to the pancreas are sectioned. IMV is usually latter divided, being approached at the inferior border of the pancreas only if the colonic partner of the anastomosis is not reaching the pelvis without tension.

We consider that, the colorectal surgeons should be familiar with all these approaches as in fact a mixed approach, combining different strategies of a single case, could be sometimes necessary, safer and less time consuming. At the end of the SFM the left colon should be mobilized caudally without any tension (Fig. 8).

All the consecutive patients who underwent splenic flexure mobilization as the first

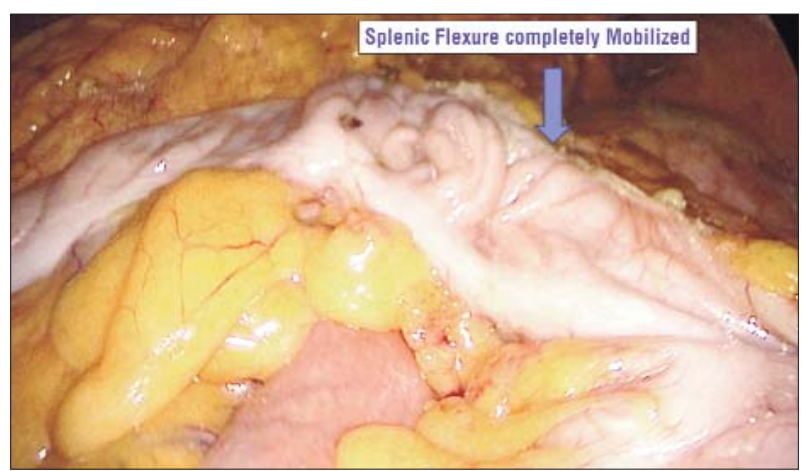

Figure 8. Laparoscopic Splenic Flexure Mobilization. Final aspect of the transverse and left colon falling down over the jejunum 
step of a minimally invasive surgery (MIS) restorative procedure in 2018 were prospectively analyzed. The study included patients with sigmoidal or rectal cancer or diverticulitis, for whom elective laparoscopic or robotic assisted surgery was indicated. The MIS Hartmann reversal procedures were also included. No patient was excluded from the study. All the patients were operated in the PONDERAS ACADEMIC HOSPITAL - designated as Center of Excellence in Colorectal by Surgical review Corporation (SRC). The preoperative work-up and the laparoscopic technique used are described above. Similar surgical strategies were applied for the robotic assisted resection and a DaVinci Xi platform was used.

There were analyzed: the time of surgery for the SFM, the type of colorectal anastomosis, the incidence of ileostomies, the perioperative complications and the procedure's early outcomes.

An informed consent was signed by all the patients and the study had the approval of the Institutional review board (IRB).

Basic statistics were used to summarize patient demographics. The analysis program used was Microsoft Excel 2016 (Microsoft, Redmond, WA, USA).

\section{Results}

Between January and December 2018, 47 patients had SPM as a first step of the performed colorectal procedure in our institution. There were 30 patients with rectal cancer, 10 with sigmoidal tumors, five with sigmoidal resection for diverticulitis and Hartmann reversal was indicated in two. The robotic approach has been used in 40\% (16 patients) of the sigmoidal or rectal tumors' cases but, the SFM was performed by laparoscopic approach, for shortening the operation time. The average time for laparoscopic SFM was 35 minutes (range, 20-65 min). All the restorative procedures were successfully performed by MIS surgery. The mean total operative time was $210 \pm 48$ minutes. Time A Side-to-end colorectal or coloanal anastomosis by means of a circular stapler was performed in 45 patients. A side-to-side colorectal anastomosis by using linear stapler was encountered in 2 patients undergoing resection for a benign pathology (Diverticulitis). Temporary diverting ileostomy was performed in 5 patients with preoperative radiotherapy who underwent low and ultralow anterior resections. Ileostomy reversal was performed in all the patients after an average time of 9 days (range, 4 to 21 days).

No intraoperative incidents were associated with the SFM. Postoperative small bowel obstruction was encountered in 2 patients with diverting ileostomy and an early reversal was decided in one. The mean postoperative hospital stay 6 days (range, $3-12$ days). No colorectal fistula was encountered. No early cancer recurrence, deaths or major complication were encountered. The mean follow-up for these patients is 7 months (range, 4-12 months). No patient was lost from follow-up.

\section{Discussions}

Nowadays, surgery for colorectal oncological or benign pathologies aims to cure the disease whilst attempting to achieve a good functional outcome. For the tumors of the mid- and lower-third of the rectum, total mesorectal excision and an anastomosis performed low in the pelvis is now a standard practice.

The functional results can be variable and depend on the integrity of the anal sphincter complex but also to the compliance of the "neo' rectum' (7). The symptoms of fecal urgency, clustering of stools and frank incontinence are termed the anterior resection syndrome and have led to an increasing tendency to fashion a colonic pouch or at least a latero-terminal anastomosis. This task cannot be accomplished with-out a well-vascularized, compliant segment of descending colon, brought down tension-free to be anastomosed to the distal rectum or anorectal junction, only after SFM.

Full mobilization of the splenic flexure and use of the descending colon for the anastomosis is certainly one way to achieve a successful restorative resection. If it is mandatory to 
always mobilize the splenic flexure is debatable and very good results with selective use of splenic flexure mobilization have been presented (6). However, if the sigmoid colon needs to be sacrificed the splenic flexure mobilization is always necessary.

Therefore, we consider that the techniques of splenic mobilization (SFM) should be part of the armamentarium of every surgeon performing colorectal surgery. The four routes for described for SFM should be technically understood and routinely applied. In our experience, a combination of different maneuvers proved to be technically easier, safer and, as consequence, it is saving surgical time. The first option for most of the cases was the medial approach but, in some patients, due to the local conditions (i.e. the small bowel is distended and difficult to deal with or difficulties in tilting the table) we found the lateral or the anterior approach more appropriate to start with. Kim $\mathrm{HJ}$ et al., found that an extended medial to lateral approach for SFM during laparoscopic low anterior resection of rectal cancer appears to be an improvement over the lateral approach, because it may provide a shorter operation time and shorter hospital stay (12).

SFM can be partial or complete. The complete option consisting of the division of the splenocolic, phrenicocolic, gastro colic and pancreaticomesocolic ligaments. In partial SFM, it is limited only to the division of splenocolic and phrenicocolic ligaments while the gastro-colic and pancreaticomesocolic attachments are not divided (9). Gezen $\mathrm{C}$ et al. demonstrated in their study the advantages of a complete SFM especially in patients who are candidates for a reservoir formation (9).

Laparoscopic mobilization of splenic flexure requires a different set-up and view for the surgical team as well as a different method of creating traction and counter-traction, compared to the open approach. Thus, SFM has been shown to be the most difficult step to learn in laparoscopic colorectal surgery (4). This may be attributed to the requirement for extensive retroperitoneal dissection without injury to the mesentery and retroperitoneal structures, such as the left ureter or pancreas. Moreover, if the need of SFM will be considered at the end of the surgery, after the rectal resection, the technical conditions are poorer as compared to the first part of the operation. The bowel is more distended, edema and blood are accumulated in left hypochondrium and, at relevant importance, the surgical team fatigue may negatively influence the technical performance and the operative time.

Nevertheless, one of the MIS colorectal surgery challenges is represented by the splenic flexure tumors. In order to deal with such complex situations, an increased surgical expertise in understanding the particular anatomy and oncological implications these tumors are needed. Moreover, for complete mesocolic excision (CME), the transverse and descending mesocolon must be dissected with an intact fascial package (7). We are confident that increasing the volume of laparoscopic SFM can support a good performance for the oncological resections in splenic flexure cancer.

Taking in consideration the above-mentioned reasons, in 2016, we have decided to routinely perform SFM as a first step of any the laparoscopic or robotic sigmoid and rectal resections.

Gaining significant experience in applying this strategy, we aimed to describe the technique of laparoscopic splenic flexure mobilization and to study prospectively all the patients who underwent SFM as the first step of MIS colorectal resections in 2018, in our hospital.

A reasonable time allocated to the SFM and without any complication associated with the procedure were demonstrated by the present study. The restorative procedure was possible in all the patients, in a site-to-end and site-tosite colorectal anastomosis without any postoperative leak. Temporary diverting ileostomy was performed only in 5 patients with preoperative radiotherapy who underwent low and ultralow anterior resections and the ileostomy reversal was performed in all the patients after an average time of 9 days (range, 4 to 21 days).

These results are demonstrating the advantages of routine specific flexure mobilization in a 
laparoscopic anterior resections (AR) or left resection: 1) Facilitates the anastomosis with a well-vascularized, compliant segment of descending colon avoiding the sigmoid colon which is often diseased and thickened; 2) Allows the fashioning the side-to- side/end or site-to-site colorectal (CR) anastomosis, known as having better functional results, with a better compliance of the 'neorectum; 3) as a consequence, a lower number of derivative ileostomies is expected; 4) It improves the leak rate and functional outcomes in the $\mathrm{CR}$ anastomosis; 5) it assures the improvement of the surgeon's expertise for difficult cases and it helps implementing standard reproducible protocols for all the left side resections

Moreover, the routine mobilization of the $\mathrm{SF}$ as a first step of the colorectal restorative resections associate more advantages: 1) a sufficient length for a tension-free anastomosis is always assured; 2) its early completion minimizes table adjustment; 3) the time for surgery is not extended: early SFM completion precludes need for later deliberation and performance; 4) it is theoretically safer as the SFM is nor performed at the end of the procedure when the operator may be fatigued.

The strategy of routinely performing SFM as the first step of the restorative colorectal resections may have opponents as some authors suggest that an extra dissection to obtain more length for the colonics partner is absolutely required only in $20-30 \%$ of the colonic/rectal resections, $(5-7,13)$. Some other drawbacks may be related to its technical complexity, the risk of affecting the left colon blood supply, colon of splenic injuries during the dissection and costs related to an extended time of surgery for an unnecessary step. All this potential, mostly technical problems may be overcome by an increased surgical experience of the colorectal surgery team.

The limitations of the study are related to the small sample size and the short time of follow- up. However, this is a prospective analyze, run in a single institution, designated as Center of Excellence in Colorectal surgery (SRC), proving very good result for the routine use of the SFM as the first step of all the CR restorative resections.

\section{Conclusions}

In our perspective, the routine mobilization of the splenic flexure as a first step of the colorectal restorative resections associate many advantages and these strategies should be largely used. There is a learning curve involved in such procedure and it can easily be overcome in high volume centers.

\section{Conflict of Interest}

The authors declare no conflicts of interests.

\section{References}

1. Wang JK, Holubar SD, Wolff BG, Follestad B, O'Byrne MM, Qin R. Risk factors for splenic injury during colectomy: a matched casecontrol study. World journal of surgery. 2011;35(5):1123-9.

2. Masoomi H, Carmichael JC, Mills S, Ketana N, Dolich MO, Stamos MJ. Predictive Factors of Splenic Injury in Colorectal Surgery: Data From the Nationwide Inpatient Sample, 2006-2008Predictive Factors of Splenic Injury. Archives of Surgery. 2012;147(4):324-9.

3. Malek MM, Greenstein AJ, Chin EH, Nguyen SQ, Sandler AL, Wong $\mathrm{RK}$, et al. Comparison of iatrogenic splenectomy during open and laparoscopic colon resection. Surg Laparosc Endosc Percutan Tech. 2007;17(5):385-7.

4. Jamali FR, Soweid AM, Dimassi H, Bailey C, Leroy J, Marescaux J. Evaluating the degree of difficulty of laparoscopic colorectal surgery. Arch Surg. 2008;143(8):762-7; discussion 8.

5. Park JS, Kang SB, Kim DW, Lee KH, Kim YH. Laparoscopic versus open resection without splenic flexure mobilization for the treatment of rectum and sigmoid cancer: a study from a single institution that selectively used splenic flexure mobilization. Surg Laparosc Endosc Percutan Tech. 2009:19(1):62-8.

6. Brennan DJ, Moynagh M, Brannigan AE, Gleeson F, Rowland M, O'Connell PR. Routine mobilization of the splenic flexure is not necessary during anterior resection for rectal cancer. Dis Colon Rectum. 2007;50(3):302-7; discussion 7.

7. Kennedy R, Jenkins I, Finan PJ. Controversial topics in surgery: Splenic flexure mobilisation for anterior resection performed for sigmoid and rectal cancer. Annals of the Royal College of Surgeons of England. 2008;90(8):638-42.

8. Taflampas P, Christodoulakis M, Tsiftsis DD. Anastomotic leakage after low anterior resection for rectal cancer: facts, obscurity, and fiction. Surgery today. 2009;39(3):183-8.

9. Gezen C, Altuntas YE, Kement M, Vural S, Civil O, Okkabaz N, et al. Complete versus partial mobilization of splenic flexure during laparoscopic low anterior resection for rectal tumors: a comparative study. Journal of laparoendoscopic \& advanced surgical techniques Part A. 2012;22(4):392-6.

10. Benseler V, Hornung M, lesalnieks I, von Breitenbuch P, Glockzin G, Schlitt HJ, et al. Different approaches for complete mobilization of the splenic flexure during laparoscopic rectal cancer resection. International journal of colorectal disease. 2012;27(11):1521-9.

11. https://livesonline.rcseng.ac.uk/biogs/E007430b.htm. Lyoyd Davies.

12. Kim HJ, Kim CH, Lim SW, Huh JW, Kim YJ, Kim HR. An extended medial to lateral approach to mobilize the splenic flexure during laparoscopic low anterior resection. Colorectal disease : the official journal of the Association of Coloproctology of Great Britain and Ireland. 2013;15(2):e93-8.

13. Martinez-Perez A, Brunetti F, Vitali GC, Abdalla S, Ris F, de'Angelis N. Surgical Treatment of Colon Cancer of the Splenic Flexure: A Systematic Review and Meta-analysis. Surg Laparosc Endosc Percutan Tech. 2017;27(5):318-27. 